\title{
PENGARUH GAYA KEPEMIMPINAN TERHADAP MOTIVASI (Studi Kasus Yayasan Nurul Ihsan)
}

\author{
Senen ${ }^{1}$, Krisnaldy ${ }^{2}$, Gos Ishak ${ }^{3}$ \\ Fakultas Ekonomi, Universitas Pamulang \\ Email: dosen01888@unpam.ac.id ${ }^{1}$, dosen01890@unpam.ac.id 2 \\ dosen00595@unpam.ac.id ${ }^{3}$
}

\begin{abstract}
Purpose. This study aims to analyze the influence of leadership style variables and work motivation variables partially and simultaneously This study also aims to analyze the influence of the variable leadership style, and work motivation on the motivation variable partially and simultaneously

Methods. The data processing method used by researchers is path analysis. The sample used in this study were 71 respondents who were taken by employees at the Nurul Ihsan Foundation. The data obtained is primary data which is the result of respondents' answers to distributed questionnaires.

Findings. The results of this study indicate that the variable leadership style (X1), 0 simultaneously affects work motivation (Y), the variable leadership style (X1), (each of which has a partial and positive effect on work motivation.

Implication. Organizations should always pay attention to leadership styles and provide motivation for the welfare that should be given to employees. namely by providing training, career development, appreciation, rewards that can support every employee who works to be more enthusiastic.
\end{abstract}

Keywords. Motivation, Leadership and Influence .

\begin{abstract}
ABSTRAK
Tujuan. Penelitian ini bertujuan untuk menganalisis pengaruh variabel gaya kepemimpinan, dan terhadap variabel motivasi kerja secara parsial dan secara simultan. Penelitian ini juga bertujuan untuk menganalisis pengaruh variabel gaya kepemimpinan, dan motivasi kerja terhadap variable motivasi secara parsial dan secara simultan
\end{abstract}

Metode. Metode pengolahan data yang digunakan peneliti adalah analisis path. Sampel yang digunakan dalam penelitian ini sebanyak 71 responden yang diambil pegawai pada Yayasan Nurul Ihsan . Data yang diperoleh merupakan data primer yang merupakan hasil dari jawaban responden atas kuesioner yang disebarkan.

Hasil. Hasil penelitian ini menunjukkan bahwa variabel gaya kepemimpinan $\left(\mathrm{X}_{1}\right)$, berpengaruh secara simultan terhadap motivasi kerja $(\mathrm{Y})$, variabel gaya kepemimpinan $\left(\mathrm{X}_{1}\right)$, masing masing berpengaruh secara parsial dan positif terhadap motivasi kerja,

Implikasi. Organisasi hendaknya selalu memperhatikan gaya kepemimpinan dan memberikan motivasi untuk kesejahteraan yang seharusnya diberikan kepada karyawan. yaitu dengan cara memberikan pelatihan, pengembangan karier, apresiasi, rewards yang mampu menunjang agar setiap pegawai yang bekerja manjadi lebih bersemangat.

Kata Kunci. Motivasi, Gaya Kepemimpinan, Pengaruh . 


\section{Pendahuluan}

Organisasi sosial dihadapkan pada tantangan besar untuk memenangkan persaingan, sehingga dibutuhkan taktik dan strategi yang akurat. Dalam pemilihan taktik dan strategi, perusahaan tidak saja memerlukan analisis perubahan lingkungan eksternal seperti demografi, sosial budaya, politik, teknologi dan persaingan, tetapi juga perlu menganalisis faktor internal perusahaan. Faktor-faktor internal yang dimaksud adalah kekuatan dan kelemahan perusahaan dalam usaha mendukung dan meraih sasaran yang ditetapkan. Faktor internal akan menyebabkan semakin buruknya kondisi perusahaan karena adanya perbedaan sikap, perasaan, pikiran dan karakteristik setiap pegawai (Ardana, 2012:17).

Ditinjau dari pemberdayaan dan penegelolaan sumber daya manusia, perusahaan perlu mewujudkan gaya kepemimpinan, , dan serta motivasi kerja pegawai sehingga dapat meningkatkan motivasi. Untuk mewujudkan hal tersebut diperlukan pengelolaan manajemen sumber daya manusia yang baik. Menurut Riani (2013:63) manajemen sumber daya manusia merupakan proses untuk mengidentifikasi, mendorong, mengukur, mengevaluasi, meningkatkan dan memberi penghargaan atas motivasi. Definisi lain diungkapkan oleh Dessler (2005) dalam Riani (2013:63) yang menyatakan bahwa manajemen sumber daya manusia adalah proses yang mengkosolidasi penetapan tujuan, penilaian kinerja dan pengembangan sistem tunggal yang bertujuan untuk memastikan bahwa motivasi mendukung dan sesuai dengan tujuan organisasi

Gaya kepemimpinan merupakan salah satu faktor yang dapat mempengaruhi Motivasi. Pendapat penulis ini sejalan dengan pendapat Ardana (2012:181) yang menyatakan bahwa kepemimpinan suatu organisasi akan mempengaruhi bawahannya, maka dengan kepemimpinan yang baik akan mempengaruhi kinerja yang baik pula. Selanjutnya Faktor lain yang dapat mempengaruhi, yang dimaksud dengan motivasi kerja adalah sesuatu yang menimbulkan dorongan atau semangat kerja atau pendorong semangat kerja.pendapat penulis ini didasarkan pendapat Ardana yang menyatakan motivasi adalah daya pendorong atau tenaga pendorong yang mendorong manusia untuk bertindak atau suatu tenaga di dalam diri manusia yang menyebabkan manusia bertindak. (Ardana, dkk, 2012:193).

Berdasarkan kerangka teori atau alur pikir tersebut maka penulis tertarik untuk menerapkannya dalam penelitian yang bertema pengaruh gaya kepemimpinan terhadap Motivasi. Untuk maksud tersebut penulis melakukan observasi dan wawancara di Yayasan Nurul Ihsan. Berdasarkan hasil wawancara observasi tersebut, diperoleh fenomena dan data sebagai berikut:

Gaya kepemimpinan yang terjadi pada Yayasan Nurul Ihsan memiliki pemimpin yang cukup baik, namun masih terdapat kekurangan yang terjadi misalnya dalam hal mengawasi kinerja kerja Santri ditambah dengan kurang adanya peranan kepemimpinan dalam menciptakan komunikasi yang harmonis serta memberikan pembinaan pegawai, akan menyebabkan tingkat motibasi rendah. Demikian halnya dengan kurangnya motivasi pegawai seperti tidak disiplin masuk kerja, malas-malasan dalam bekerja akan menyebabkan motivasi rendah. Setiap pemimpin pada dasarnya memiliki perilaku yang berbeda dalam memimpin para pengikutnya, perilaku para pemimpin itu disebut dengan gaya kepemimpinan. Kurangnya komunikasi pimpinan terjadi pada yayasan nurul Ihsan hal ini terlihat berdasarkan hasil wawancara dari Yayasan Nurul Ihsan terhadap Santri, kurangnya komunikasi pemimpin pada santri menyebabkan kurangnya motivasi, karena santri merasa kurang diperhatikan oleh pimpinan.

Fenomena lainnya dalam hal, pada Yayasan Nurul Ihsan, para pemimpin telah berusaha mengatasi kedisiplinan cukup ketat dan membuat beberapa sanksi jika melakukan kesalahan namun hal tersebut masih saja adanya kurang sadarnya santri dalam mematuhi aturan yang ditetapkan. Fenomena lain yang terjadi adalah mengenai motivasi kerja, kebijakan lainya yang dilakukan organisasi dalam meningkatkan motivasi dilakukan dengan memberikan fasilitas bagi santri dalam upaya memberikan motivasi dan kepuasan dalam upaya peningkatan motivasi yang lebih baik lagi., Yayasan Nurul Ihsan merupakan instansi sosial yang memberikan pengahrgaan bagi Santriya sesuai dengan kontribusi dan prestasinya, 
Berdasarkan kerangka teori (alur pikir) maka penulis tertarik untuk melakukan dan menerapkannya dalam penelitian yang bertema judul Penelitian "PENGARUH GAYA KEPEMIMPINAN TERHADAP MOTIVASI (Studi Kasus Yayasan Nurul Ihsan).

\section{Kajian Pustaka dan Hipotesis}

Manajemen Sumber Daya Manusia. Manajemen sumber daya manusia pada umumnya untuk memperoleh tingkat perkembangan Santri yang setinggi-tingginya, hubungan kerja yang serasi di antara para Santri dan penyatupaduan sumber daya manusia secara efektif atau tujuan efisiensi dan kerja sama sehingga diharapkan akan meningkatkan produktivitas kerja (Sunyoto, 2012:1).

Manajemen sumber daya manusia adalah suatu perencanaan, pengorganisasian, pengarahan dan pengawasan atas pengadaan, pengembangan, , pengintegrasian, pemeliharaan dan pemutusan hubungan kerja dengan maksud untuk mencapai tujuan organisasi perusahaan secara terpadu Umar dalam Sunyoto (2012:1). Manajemen sumber daya manusia merupakan bagian dari manajemen keorganisasian yang memusatkan perhatian pada unsur manusia. Unsur manusia (Man) ini berkembang menjadi suatu bidang ilmu khusus untuk mempelajari bagaimana mengatur suatu bidang ilmu khusus untuk mempelajari bagaimana proses pemanfaatan sumber daya manusia secara efektif dan efisien untuk mencapai tujuan tertentu dan dapat memberikan kepuasan bagi semua pihak. MSDM adalah suatu bidang manajemen yang mempelajari hubungan dan peranan manusia dalam organisasi atau perusahaan (Ardana, et al, 2012:3).

Motivasi. Motivasi ditinjau dari ilmu manajemen merupakan suatu fungsi atau alat yang erat kaitannya dengan manusia sebagai penggerak orang-orang agar mampu melakukan kegiatankegiatan organisasi. Bagi pimpinan organisasi kegiatan manajemen penting dalam meningkatkan produktivitas organisasi. Menurut Sutrisno (dalam Hadi, 2019:216) berpendapat bahwa Motivasi adalah suatu faktor yang mendorong seseorang untuk melakukan aktivitas tertentu, oleh karena itu motivasi sering kali diartikan pula sebagai faktor pendorong perilaku seseorang.

Dimensi Gaya Kepemimpinan. Dalam menentukan dimensi gaya kepemimpinan, menurut sepengetahuan dan sebatas pengetahuan penulis sampai saat ini belum ada pakar atau ahli yang menjelaskan secara tersurat tentang dimensi gaya kepemimpinan tetapi yang penulis ketahui para pakar hanya menjelaskan secara tersirat tentang dimensi gaya kepemimpinan yang dapat dijelskan sebagai berikut:

1) Gaya kepemimpinan Otokratis, faktor pemimpin pilihan pada pola perilaku ini didukung oleh pemilikan power yang amat kuat, kehendak mempertahankan posisi dan mempunyai pandangan bahwa situasi yang dihadapi dalam suasana yang kritis. Dari faktor pengikut cenderung memilih gaya kepemimpinan pengikutnya sangat bergantung pada pemimpin, mengakui situasi kritis dan tidak menuntut adanya kebebasan. Berdasarkan situasi kerja menuntut kedisiplinan, pengawasan yang ketat dan memerlukan skill yang rendah.

2) Gaya kepemimpinan Demokratis, dari faktor pimpinan pilihan pada gaya ini didukung oleh suatu kesadaran bahwa pemilikan power yang terbatas, adanya kelompok penentang, waktunya serba terbatas, serta tidak mudah memberikan sanksi, dari segi pengikut menghendaki pemberian otoritas, mempunyai kebutuhan sosial yang tinggi dan dari segi situasi kerja adanya rasa tanggung jawab bersama, koordinasi dan kerja team.

Menurut Sutikno (2014:35-41) terdapat tujuh tipe kepemimpinan yang dikenal luas dan diakui keberadaanya yaitu, tipe otokratik, tipe kendali bebas, tipe paternalistik, tipe kharismatik, tipe militeristik, tipe pseudo-demokratik dan tipe demokratik. Berikut ini penjelasanya:

1) Tipe Otokratik

Tipe kepemimpinan ini menganggap bahwa kepemimpinan adalah hak pribadinya (pemimpin), sehingga ia tidak perlu berkonsultasi dengan orang lain dan tidak boleh ada orang lain yang turut campur. Seorang pemimpin yang tergolong otokratik memiliki serangkaian karakteristik yang biasanya dipandang sebagai karakteristik yang negatif. 
2) Tipe Kendali Bebas / Masa Bodo (Laisez Faire)

Tipe kepemimpinan ini merupakan kebalikan dari tipe kepemimpinan otokratik. Dalam kepemimpinan tipe ini sang pemimpin biasanya menunjukkan perilaku yang pasif dan sering kali menghindari diri dari tanggung jawab.

3) Tipe Paternalistik

Persepsi seorang pemimpin yang paternalistik tentang perannya dalam kehidupan organisasi dapat dikatakan diwarnai oleh harapan bawahan kepadanya.

4) Tipe Kharismatik

Seorang pemimpin yang kharismatik memiliki karakteristik khusus yaitu daya tariknya yang sangat memikat, sehingga mampu memperoleh pengikut yang sangat besar dan para pengikutnya tidak selalu menjelaskan secara konkrit mengapa orang tertentu itu dikagumi.

5) Tipe Militeristik

Pemimpin tipe militeristik berbeda dengan seorang pemimpin organisasi militer, pemimpin yang bertipe militeristik ialah pemimpin dalam menggerakkan bawahannya lebih sering menggunakan sistem perintah, senang bergantung pada pangkat dan jabatan, dan senang kepada formalitas yang berlebih-lebihan.

6) Tipe Pseudo-Demokratik

Tipe ini disebut juga kepemimpinan manipulatif atau semi demokratik, tipe kepemimpinan ini ditandai oleh adanya sikap seorang pemimpin yang berusaha mengemukakan keinginan- keinginannya dan setelah itu membuat sebuah panitia, dengan berpura pura untuk berunding tetapi yang sebenarnya tiada lain untuk mengesahkan saran-sarannya.

7) Tipe Demokratik

Yang dimaksud dengan tipe demokratik adalah tipe memimpin yang demokratis dan bukan karena dipilihnya pemimpin secara demokratis.

\section{Keterkaitan antara Variabel Gaya Kepemimpinan terhadap Motivasi Kerja}

Pemimpin merupakan seseorang yang memiliki kemampuan memimpin artinya memiliki kemampuan untuk mempengaruhi prilaku orang lain (Thoha, 1983) dalam (Ardana, dkk, 2012:179). Dalam menanggulangi masalah seorang pemimpin dibutuhkan untuk mengambil keputusan agar masalah dapat selesai (Subkhi dan Jauhar, 2013:145). Kepemimpinan adalah pengetahuan atau seni yang secara sisitimatis mampu mempengaruhi anggota kelompoknya untuk mencapai tujuan bersama sehingga pemimpin adalah orang yang mampu menumbuhkan respek dari orang lain kepada dirinya sehingga orang lain mau melakukan apa yang ia inginkan disini seorang pemimpin harus mampu menjual gagasan kepada anggota kelompoknya. Pemimpin yang berhasil hendaknya memiliki beberapa kriteria yang tergantung pada sudut pandang atau pendekatan yang digunakan, apakah itu kepribadiannya, ketrampilan, bakat, sifat-sifatnya atau kewenangan yang dimiliki yang mana nantinya sangat berpengaruh terhadap teori maupun gaya kepemimpinan yang akan diterapkan (Wahyuningsih, dkk, 2013:3).Menurut Sutikno (2014:135) menyatakan bahwa seorang pemimpin harus dapat membangkitkan inner motivation dari orang yang dimpimpinnya dengan menetapkan berbagai misi atau sasaran yang akan dicapai. Sebagai pimpinan perlu berbagi tim untuk secara bersama melihat visi secara jelas dan bagaimana melakukannya

Berdasarkan teori dan tujuan dari penelitian untuk mengetahui pengaruh gaya kepemimpinan, dan terhadap motivasi kerja, dalam mewujudkan kinerja Santri dalam bekerja perlu adanya analisa mengenai faktor apa saja yang dapat mempengaruhinya, berdasarkan beberapa teori dan sumber perlu adanya suatu motivasi dari perusahaan dalam meningkatkan kinerja dengan melakukan gaya kepemimpinan yang sesuai keinginan pegawai, sehingga akan terjalin suatu kerja sama yang baik.

\section{Hipotesis Penelitian}

Berdasarkan pada kajian yang telah diuraikan dalam latar belakang masalah, landasan teori, penelitian terdahulu dan kerangka pemikiran teoritis, maka hipotesis yang diajukan untuk diuji dalam penelitian ini adalah sebagai berikut: 
$\mathrm{H}_{\mathrm{a}}$ : Terdapat pengaruh antara variabel gaya kepemimpinan terhadap variabel Motivasisecara parsial.

$\mathrm{H}_{\mathrm{o}}$ : Tidak terdapat pengaruh antara variabel gaya kepemimpinan terhadap variabel Motivasisecara parsial.

\section{Metode Penelitian}

Jenis penelitian yang digunakan dalam penelitian ini adalah menggunakan metode kuantitatif deskriptif, menurut Sugiyono (2013:13) penelitian kuantitatif dapat diartikan sebagai metode penelitian yang berlandaskan pada filsafat positivisme. Digunakan untuk meneliti pada populasi atau sampel tertentu. Dan statistik deskriptif menurut Sugiyono (2013:206) adalah statistik yang untuk menganalisa data dengan cara mendePenelitiankan atau menggambarkan data yang telah terkumpul sebagaimana adanya tanpa bermaksud membuat kesimpulan yang berlaku untuk umum atau generalisasi.

\section{Uji Instrumen Penelitian}

Dalam suatu penelitian, data mempunyai kedudukan yang sangat penting. Hal ini dikarenakan data merupakan penggambaran variabel yang diteliti dan berfungsi sebagai alat pembuktian hipotesis. Valid atau tidaknya data sangat menentukan kualitas dari data tersebut. Hal ini tergantung instrumen yang digunakan apakah sudah memenuhi asas validitas dan reliabilitas. Adapun dalam pengujian instrumen ini digunakan 2 (dua) pengujian yaitu validitas dan reliabilitas.

\section{Uji Asumsi Klasik}

Uji asumsi klasik digunakan untuk mengetahui ketepatan sebuah data. Menurut Santoso (2015:342) berpendapat "Sebuah model regresi akan digunakan untuk melakukan peramalan sebuah model yang baik adalah model dengan kesalahan peramalan yang seminimal mungkin. Karena itu, sebuah model sebelum digunakan seharusnya memenuhi beberapa asumsi, yang biasa disebut asumsi klasik". Dalam penelitian ini uji asumsi klasik yang digunakan: Uji Normalitas, Uji Multikolinearitas, Uji Autokorelasi, dan Uji Heterokedastisitas.

\section{Analisis Kuantitatif}

Analisis kuantitatif adalah penelitian untuk menilai kondisi dari nilai pengaruh, dan signifikansi pengaruh tersebut. Dalam penelitian ini analisis kuantitatif yang digunakan: Analisis Regresi Linier Sederhana, Linier Berganda, Analisis Koefisien Korelasi, Analisis Koefisien Determinasi, Pengujian Hipotesis.

\section{Hasil Penelitian dan Pembahasan Uji Validitas Instrumen}

Dalam penelitian ini penulis menggunakan metode analisis deskriptif, karena adanya variabel-variabel yang akan ditelaah hubungannya serta tujuannya untuk menyajikan gambaran yang terstruktur, factual dan akurat mengenai fakta-fakta serta hubungan antara variabel yang diteliti. Penulis juga melakukan analisis terhadap data yang telah diuraikan dengan menggunakan metode kuantitatif. Definisi metode kuantitatif menurut Sugiyono (2013:3), yaitu metode kuantitatif merupakan metode ilmiah atau scientific karena telah memenuhi kaidah-kaidah ilmiah yaitu konkrit atau empiris, obyektif, terukur, rasional, dan sistematis.

Analisis dapat dilanjutkan dengan menghitung persamaan regresinya. Persamaan regresi juga dapat digunakan untuk melakukan prediksi seberapa tinggi nilai variabel independen dimanipulasi (diubah-ubah). Analisis regresi yaitu untuk mengetahui hubungan yang ada atau diperkirakan ada diantara variabel X (Motivasi) dan variabel Y (Kinerja Karyawan). Analisis regresi dari satu variabel bebas $(\mathrm{X})$ dan satu variable terikat $(\mathrm{Y})$ dengan cara mencari besarnya koefisiensi persamaan garis regresi dan menafsirkannya maksud dari koefisien persamaan 
garis yang telah didapat. Koefisien persamaan garis regresi sederhana dapat dicari atau dihitung dengan menggunakan rumus koefisien regresi sebagai berikut:

$$
\mathrm{Y}=\mathrm{a}+\mathrm{bX}
$$

Keterangan:

Y= Subyek/nilai dalam variabel dependen yang diprediksikan.

$\mathrm{X}=$ Subjek pada variabel independen yang mempunyai nilai tertentu

$\mathrm{a}=$ Harga $\mathrm{Y}$ bila $\mathrm{X}=0$ (harga konstan)

$\mathrm{b}=$ Besarnya pengaruh $\mathrm{X}$ terhadap $\mathrm{Y}$ atau angka arah (koefisien regresi)

Nilai a dan b diperoleh dengan menggunakan rumus sebagai berikut:

$$
\begin{aligned}
& \mathrm{a}=\frac{\left(\sum Y\right)\left(\sum_{X} 2\right)-\left(\sum X\right)\left(\sum X Y\right)}{n\left(\sum_{X} 2\right)-\left(\sum X\right) 2} \\
& \mathrm{~b}=\frac{n\left(\sum x y\right)-\left(\sum x\right)\left(\sum y\right)}{n\left(\sum_{x^{2}}\right)\left(\sum x\right) 2}
\end{aligned}
$$

Keterangan:

$\mathrm{X}=$ Variabel Independen

$\mathrm{Y}=$ Variabel Dependen

$\mathrm{a}=$ Konstana/nilai Y jika X : 0

$\mathrm{b}=$ Koefisien Arah/Nilai Pertambahan/Pengurangan Variabel Y

$\mathrm{n}=$ Banyaknya Sampel Data

Untuk mengetahui nilai regresi dalam penelitian ini, penulis menghitung dan menganalisanya dengan menggunakan software SPSS (Statistical Program For Science) versi 20 for windows. Sehingga proses pengukuran dan pengujiannya lebih cepat, efektif, efisien dan akurasinya tinggi.

\section{Analisis Korelasi}

Dalam penelitian ini dilakukan pula uji korelasi dan teknik yang digunakan dalam penelitian ini adalah korelasi person product moment :

$$
r x y=\frac{n \sum X Y-\sum X \cdot \sum Y}{\sqrt{\left(n \cdot \sum X^{2}-\left(\sum X\right)^{2}\right\}\left[n \cdot \sum Y^{2}-\left(\sum Y\right)^{2}\right\}}}
$$

Keterangan :

$$
\begin{array}{ll}
r x y & =\text { Kofisien korelasi } \\
X & =\text { Variabel bebas (Motivasi) } \\
Y & =\text { Variabel terikat (Kinerja Karyawan) } \\
\Sigma X^{2} & =\text { Jumlah kuadrat pernyataan X } \\
\Sigma Y^{2} & =\text { Jumlah kuadrat pernyataan } Y \\
n & =\text { Jumlah Sampel }
\end{array}
$$

Tabel 1. Pedoman Untuk Memberikan Interprestasi Kofisien Korelasi

\begin{tabular}{|c|c|}
\hline Internal Koefisien & Tingkat Hubungan \\
\hline $0,00-0,199$ & Sangat rendah \\
$0,20-0,399$ & Rendah \\
$0,40-0,599$ & Sedang \\
$0,60-0,799$ & Kuat \\
$0,80-1,000$ & Sangat kuat \\
\hline
\end{tabular}

Pada hakekatnya $r$ bervariasi antara -1 hingga +1 , apabila $=0$ atau mendekati 0 , maka hubungan antara kedua variabel sangat lemah atau tidak ada hubungan sama sekali. 
Sedangkan apabila $r=1$ atau mendekati 1, maka korelasi antara kedua variabel tersebut dikatakan positif dan memiliki pengaruh antara variabel $\mathrm{X}$ dan variabel $\mathrm{Y}$.

\section{Hasil Uji Determinasi (R)}

Untuk mengetahui kontribusi besarnya pengaruh variabel Gaya Kepemimpina terhadap Motivasi dapat dijelaskan sebagai berikut:

Tabel 2. Hasil Uji Determinasi (R) Model Summary

\begin{tabular}{|c|c|c|c|c|}
\hline Model & $\mathrm{R}$ & R Square & $\begin{array}{c}\text { Adjusted R } \\
\text { Square }\end{array}$ & $\begin{array}{c}\text { Std. Error of } \\
\text { the Estimate }\end{array}$ \\
\hline 1 & $.789 \mathrm{a}$ & .622 & .616 & 2.502 \\
\hline
\end{tabular}

a. Predictors: (Constant), Motivasi (X)

Sumber: Data primer yang telah diolah dengan SPSS versi 20

Dari tabel diatas dapat dilihat bahwa nilai R Square sebesar 0,622 atau sebesar 62,2\% hal ini menunjukan bahwa variabel motivasi memberikan kontribusi terhadap kinerja karyawan sebesar $62,2 \%$ sisanya $37,8 \%$ dipengaruhi oleh variabel lain yang tidak diteliti oleh peneliti (disiplin kerja, kompensasi, budaya organisasi dan lain-lain) yang tidak diteliti dalam penelitian ini.

\section{Kesimpulan}

Dari hasil penelitian menunjukan bahwa, dari hasil korelasi $r$ sebesar 0 , , dapat disimpulkan bahwa terdapat pengaruh yang kuat antara Gaya kepemimpinan terhadap Motivasi pada Yayasan Nurul Ihsan. Hasil koefisien determinasi menunjukan bahwa Gaya Kepemimpian memberikan kontribusi sumbangan sebesar 62,2\% terhadap Motivasi pada Yayasan Nurul Ihsan.. Persamaan regresi linear sederhana $\mathrm{Y}=14,519+0,637 \mathrm{X}$ dapat disimpulkan bahwa, tanpa variabel motivasi besarnya nilai kinerja karyawan tetap terbentuk 14,519 dan jika motivasi sama dengan nol (0) atau diabaikan, maka setiap kenaikan satusatuan akan mengakibatkan kenaikan Motivasi k sebesar 0,637. Pada uji hipotesis $2 h$ 回国回回 > 国国回国 $(9,778>2,002)$. Maka Ho ditolak dan Ha diterima, sehingga hipotesis penulis diterima bahwa terdapat pengaruh yang positif dan signifikan antara gaya kepemimpian terhadap motivasii pada Yayasan Nurul Ihsan.

\section{Daftar Pustaka}

A.A.Anwar Prabu Mangkunegara (2012). Manajemen Sumber Daya Manusia Perusahaan. PT. Rosda Karya : Bandung

Arikunto, S. (2014). Prosedur Penelitian Suatu Pendekatan Praktik. Jakarta : Rineka Cipta.

Batjo, Nurdin, \& Mahadin, S. (2018). Manajemen Sumber Daya Manusia. Cetakan Pertama. Aksara Timur: Makassar.

Dessler, G. (2015). Manajemen Sumber Daya Manusia. Jakarta: Salemba Empat.

Eka, P.D., Agusentoso, R., Suwanto, S., Aldy, H.L.N. and Gandung, M., 2020. PENGELOLAAN KEUANGAN PONPES DALAM RANGKA PENINGKATAN MASYARAKAT MANDIRI DI PANTI ASUHAN IKHWANIYAH CINTA YATIM DAN DHUAFA. Jurnal Pengabdian Dharma Laksana, 3(1),

Ghozali, I., \& Ratmono, D. (2017). Analisis Multivariat dan Ekonometrika dengan Eviews 10. Semarang: Badan Penerbit Universitas Diponegoro.

Hasibuan, M. S. P. (2018). Manajemen Sumber Daya Manusia. Cetakan ke-20. Jakarta: PT.Bumi Aksara.

Hermawati, R., Indriyani, S. (2019). Pengaruh Rekrutmen dan Kompensasi Terhadap Kinerja Karyawan Pada PT. Sinergi Inti Pelangi. Jurnal Jenius, 3(1), 24-41.

Kanto, M., Rappana, P. (2017). Filsafat Manajemen. Jakarta : Celebes Media Perkasa. 
Komarudin. (2018). Pengaruh Pelatihan Dan Motivasi Terhadap Produktivitas Kerja Karyawan PT. Lion Mentari Airlines Bandara Soekarno Hatta Cengkareng. Jurnal Ilmiah Manajemen Forkamma, 1(2), 128-145.

Kusjono, G., Ratnasari, P. (2019). Pengaruh Motivasi Dan Kompensasi Terhadap Kinerja Karyawan Pada PT. Sumber Tenaga Lestari (Citylight Apartment) Tangerang Selatan. Jurnal Jenius. 2(2), 224-242.

Larasati, S. (2018). Manajemen Sumber Daya Manusia. Yogyakarta: Deepublish.

Maduningtias, L. (2019). Pengaruh Lingkungan kerja dan Budaya Organisasi Terhadap Produktivitas Karyawan Pada PT. L'Essential. Jurnal Jenius, 2(3), 394-400.

Mangkunegara, A. P. (2013). Manajemen Sumber Daya Manusia Perusahaan. Bandung: PT. Remaja Rosda Karya.

Marayasa, I. N., Faradila, A. (2019). Pengaruh Motivasi Dan Disiplin Kerja Terhadap Kinerja Karyawan PT. Bank Dinar Indonesia. Jurnal Ekonomi Efektif , 2(2), 110-122.

Marjuni, S. (2015). Manajemen Sumber Daya Manusia. Makassar: CV. Sah Media.

Masram, \& Mu'ah. (2015). Manajemen Sumber Daya Manusia. Bandung: Zifatama Publisher.

Paeno. (2018). Pengaruh Motivasi dan Disiplin Terhadap Produktivitas Pada PT. Agra Energi Indonesia. Jurnal Jenius, 1(3), 290-306.

Pasaribu, V. L. D., \& Krisnaldy, K. (2018). Analisis Kepuasan Jamaah Pada Masjid Raya Alhidayah Pamulang. KREATIF: Jurnal Ilmiah Prodi Manajemen Universitas Pamulang, 6(4), 41-51.

Puspita, W. (2018). Manajemen Konflik: Suatu Pendekatan Psikologi, Komunikasi dan Pendidikan.Yogyakarta: Deepublish.

Santoso, S. (2015). Menguasai Statistik Multivariat. Jakarta : PT Elex Media Komputindo.

Sari, R. (2019). Pengaruh Kompensasi Terhadap Kinerja Karyawan Pada PT Perma Plasindo Jakarta. Jurnal Disrupsi Bisnis, 2(2), 48-62.

Sugiyono. (2016). Metode Penelitian Kuantitatif, Kualitatif dan R\&D. Bandung: PT Alfabet. . (2017). Metode Penelitian Kuantitatif, Kualitatif dan R\&D. Bandung: PT Alfabet.

Sunarsi, D. (2018). Pengaruh Motivasi dan Disiplin Terhadap Produktivitas Kerja Karyawan Pada PT. Nadi Suwarna Bumi. Jurnal Ilmiah semarak, 1(1), 66-82.

Supangat, . (2015). Statistika dalam Kajian Deskriftif, Inferensi dan Non parametrik. Edisi Pertama. Jakarta: Kencana Prenada Media Group.

Suryani, N. L., Hastono. (2020). Pengaruh Kompensasi dan Kepuasan Kerja Terhadap Kinerja Karyawan Pada PT. Mitra Agung Persada Di Jakarta. Jurnal Jenius, 3(3), 322-332.

Sutrisno, E . (2012). Manajemen Sumber Daya Manusia. Jakarta: Kencana. 